\title{
The role of antiperipheral nerve antibodies in nerve damage in leprosy
}

\author{
PRABHA DESIKAN*§, OM PARKASH $† \&$ \\ PRATIBHA NARANG $\ddagger$ \\ *Christian Medical College \& Hospital, Vellore, India; †Central \\ JALM A Institute for Leprosy, Agra, India; and $\ddagger$ Mahatma Gandhi \\ Institute of Medical Sciences, Sewagram, India
}

\section{Accepted for publication 21 February 1994}

\begin{abstract}
Summary The objective of this study was to determine the role of antineural antibodies in leprosy. Indirect ELISA using antigen prepared from normal human peripheral nerves was carried out on the sera from 100 leprosy patients and 18 normal controls. In total, $9 \%$ of the patients had demonstrable levels of IgG antineural antibodies and $11 \%$ had demonstrable levels of IgM antibodies. There was no correlation with the type of leprosy, bacteriological index, treatment taken, the presence of a reactional state, the presence of enlarged nerves or active neuritis.
\end{abstract}

\section{Introduction}

The role of antineural antibodies in leprosy directed against peripheral nervous system components is, to date, inconclusive and controversial. There is always some degree of nerve damage throughout the whole spectrum of the disease. However, it has not always been possible to elucidate the exact pathogenesis of nerve damage in cases with neuropathies, keeping in perspective the available information on the subject. ${ }^{2,4,7,8,14}$ Hence, it is postulated that an autoimmune mechanism may be responsible in leprosy either as a primary process leading to nerve damage, or as a secondary process perpetuating an already existing nerve damage. ${ }^{17}$

\section{Materials and methods}

STUDY SUBJECTS

Keeping in perspective the results obtained from previous studies, which ranged from 0

$\S$ Correspondence: Dr Prabha Desikan, The Wellcome Trust Research Laboratory, Department of Gastrointestinal Sciences, Christian Medical College \& Hospital, Vellore 632 004, India.

T Work done at: the Department of Microbiology, Mahatma Gandhi Institute of Medical Sciences, Sewagram 442 102, India. 
Table 1. Duration of the disease in all leprosy patients tested

\begin{tabular}{lcccc}
\hline $\begin{array}{l}\text { Type of } \\
\text { leprosy }\end{array}$ & $\begin{array}{c}\text { Total no. } \\
\text { of cases }\end{array}$ & $\begin{array}{c}\text { Cases with disease } \\
\text { duration }<1 \text { yr }\end{array}$ & $\begin{array}{c}\text { Cases with disease } \\
\text { duration } 1-4 \text { yr }\end{array}$ & $\begin{array}{c}\text { Cases with disease } \\
\text { duration }>4 \text { yr }\end{array}$ \\
\hline LL & 43 & 5 & 25 & 13 \\
BL & 18 & 1 & 12 & 5 \\
BB & 3 & 2 & 0 & 1 \\
BT & 34 & 10 & 20 & 0 \\
TT & 2 & 1 & 1 & 23 \\
\hline Total & 100 & 19 & 58 & \\
\hline
\end{tabular}

through $4 \cdot 1,13,22,23 \cdot 86,25,25 \cdot 6,40,47$ to $100 \%$, the average $(31 \%)$ was taken as the anticipated population proportion having antineural antibodies. The sample size required for this anticipated population proportion was calculated using a $95 \%$ confidence interval and a precision of 9 percentage points. The minimum sample size was found to be 100 , when calculated according to the formula:

$$
\frac{n=Z_{\alpha}^{z} \times p \times(1-p)}{d^{2}}
$$

where $n$ is the sample size, $z$ is the standard normal curve value at $1-\alpha / 2,100(1-\alpha)$ is the confidence interval, $p$ is the anticipated population proportion and $d$ is the percentage point. Thus serum from 100 leprosy patients were studied. Representative samples from the entire spectrum of the disease were collected and tested. The patients were classified according to the Ridley-Jopling classification of leprosy. ${ }^{15}$

There were 43 patients with lepromatous leprosy (LL), 18 with borderline lepromatous (BL) leprosy, 3 with borderline (BB) leprosy, 34 with borderline tuberculoid (BT) leprosy and 2 with polar tuberculoid (TT) leprosy. Out of the total 100 patients, 35 were cases in reaction, 20 with Type I and 15 with Type II reaction. The duration of the disease in the patients ranged from 4 months to 11 years. Duration of the disease in all cases at the time of collection of serum samples for the study is shown in Table 1. In all, 52 of the patients had enlarged peripheral nerves, of whom 19 had signs of active neuritis, as detailed in Table 2. The patients were aged between 14 and 60 years and 61 patients had bacteriological indices $(\mathrm{BI})$ ranging between 0 and $2+, 30$ had $\mathrm{BI}>2+$; the BI of 9 patients were not known, and 67 patients were on multidrug therapy for leprosy.

Table 2. Leprosy patients with clinical evidence of nerve involvement

\begin{tabular}{lccc}
\hline $\begin{array}{l}\text { Type of } \\
\text { leprosy }\end{array}$ & $\begin{array}{c}\text { Total no. } \\
\text { of cases }\end{array}$ & $\begin{array}{c}\text { Cases with } \\
\text { nerve enlargement }\end{array}$ & $\begin{array}{c}\text { Cases with } \\
\text { active neuritis }\end{array}$ \\
\hline LL & 43 & 17 & 6 \\
BL & 18 & 14 & 5 \\
BB & 3 & 1 & 0 \\
BT & 34 & 18 & 7 \\
TT & 2 & 2 & 1 \\
\hline Total & 100 & 52 & 19 \\
\hline
\end{tabular}


Table 3. Control sera used in the study

\begin{tabular}{lc}
\hline Type of sera & No. of sera \\
\hline I Normal healthy controls & 18 \\
II Controls with neurological deficiencies due to & \\
causes other than leprosy: & \\
a Gullian-Barré syndrome & 2 \\
b Abortive Gullian-Barré syndrome & 1 \\
c Diabetic neuropathy & 4 \\
d Motor neuron disease & 3 \\
e Paraparesis & 2 \\
f Polio & 1 \\
g Anterior horn cell disease (other than polio) & 1 \\
h Crush injury & 1 \\
j Neurofibromatosis & 1 \\
k Viral encephalitis with sensory deficiency & 1 \\
l Post-diphtheritic bilateral VI nerve palsy with left VII nerve palsy & 1 \\
m Neuropathy due to unknown aetiology & 4 \\
\hline Total & 41 \\
\hline
\end{tabular}

The remaining patients had not received any treatment for leprosy. Control sera were included in the study. There were normal healthy controls as well as controls with neurological deficits due to causes other than leprosy, as detailed in Table 3.

\section{ANTIGEN PREPARATION}

Normal human nerves were taken at autopsy within $1 \mathrm{hr}$ of death and teased. They were treated with warm acetone $\left(37^{\circ} \mathrm{C}\right)$ and petroleum ether and then homogenized and sonicated. The protein content was $1.2 \mathrm{mg} / \mathrm{ml}$, calculated by Lowry's method. ${ }^{9}$ The major bands migrated at $15-22 \mathrm{kDa}$ and $25-27 \mathrm{kDa}$.

\section{ELISA}

Indirect ELISA using $60 \mathrm{ng}$ of antigen per well (after checker board titration) was carried out using U-bottomed polystyrene Nunc Immunoplates. Briefly, the coated plates were kept overnight at $37^{\circ} \mathrm{C}$ in a moist chamber and washed next morning 3 times with PBST. Blocking was done with 3\% BSA in PBS-T. The sera was diluted at 1:400 and the plates were incubated at $37^{\circ} \mathrm{C}$ for $1 \mathrm{hr}$ in a moist chamber and washed with PBS-T. To test for IgG type of antibodies, $50 \mu$ l of antihuman IgG conjugated with HRPO (Lupin) at a dilution of $1: 1000$ in PBS-T per well was used. In order to test for IgM antibodies, $50 \mu \mathrm{l}$ of antihuman IgM conjugated with HRPO at a dilution of $1: 1000$ in PBS-T per well was used. Plates were incubated at $37^{\circ} \mathrm{C}$ in a moist chamber for $1 \mathrm{hr}$ and washed with PBS-T. Orthophenylene diamine (Sigma) with 30\% hydrogen peroxide was used as a substrate. The reaction was stopped using $7 \%$ sulphuric acid. The optical density was read after 10-20 min using $492 \mathrm{~nm}$ filter in a Titertek Multiscan plus ELISA reader from 
Table 4. Details of cases with demonstrable levels of IgG antibody

\begin{tabular}{|c|c|c|c|c|c|c|}
\hline $\begin{array}{l}\text { Type of } \\
\text { leprosy }\end{array}$ & $\mathrm{A} / \mathrm{S}$ & $\begin{array}{l}\text { Duration } \\
\text { of disease }\end{array}$ & BI & $\begin{array}{c}\text { Nerve } \\
\text { enlargement }\end{array}$ & $\begin{array}{l}\text { Active } \\
\text { neuritis }\end{array}$ & $\begin{array}{c}\text { Whether on } \\
\text { treatment }\end{array}$ \\
\hline LL & 33/M & $2 \mathrm{yr}$ & $3+$ & + & + & - \\
\hline LL & $45 / \mathrm{M}$ & $10 \mathrm{yr}$ & $2+$ & - & - & + \\
\hline LL & $40 / \mathrm{M}$ & 8 months & $3+$ & - & - & + \\
\hline LL & $28 / \mathrm{M}$ & $1 \mathrm{yr}$ & $5+$ & - & - & + \\
\hline BL & $22 / \mathrm{F}$ & Relapsed 1 yr ago & Not known & + & + & + \\
\hline BT & $30 / \mathrm{F}$ & $3 \mathrm{yr}$ & - ve & + & + & + \\
\hline BT & $65 / \mathrm{M}$ & $1 \mathrm{yr}$ & $-\mathrm{ve}$ & + & - & + \\
\hline BT & $25 / \mathrm{M}$ & $2 \mathrm{yr}$ & $-\mathrm{ve}$ & - & - & + \\
\hline BT & $25 / \mathrm{F}$ & $1 \mathrm{yr}$ & $-\mathrm{ve}$ & + & - & - \\
\hline
\end{tabular}

Flow Laboratories. All assays were done in triplicate. The cut-off values for sero reactivity were determined by adding $2 \mathrm{SD}$ to the mean absorbance of the healthy controls who had no apparent neurological damage.

\section{Results}

Out of 18 normal controls, one (5.6\%) had significant levels of antineural antibodies of the IgM type and none had significant levels of antineural antibodies of the IgG type. Out of the neurological diseases other than leprosy, the sera obtained from the 2 Guillian-Barré syndrome sufferers had significant levels of antineural antibodies of the IgG type, whereas none of sera from the other diseases had any significant levels of these antibodies.

In total, 9 leprosy patients (9\%) had significant levels of $\operatorname{IgG}$ antibodies and 11 patients $(11 \%)$ had significant levels of IgM antineural antibodies. They formed 2 largely nonoverlapping groups with only 2 patients positive for both isotypes. The clinical and bacteriological details of these 2 groups are given in Tables 4 and 5. The optical density values obtained with ELISA for the sera of leprosy patients and normal controls are

Table 5. Details of cases with demonstrable levels of IgM antibody

\begin{tabular}{|c|c|c|c|c|c|c|}
\hline $\begin{array}{l}\text { Type of } \\
\text { leprosy }\end{array}$ & $\mathrm{A} / \mathrm{S}$ & $\begin{array}{l}\text { Duration } \\
\text { of disease }\end{array}$ & $\mathrm{BI}$ & $\begin{array}{c}\text { Nerve } \\
\text { enlargement }\end{array}$ & $\begin{array}{l}\text { Active } \\
\text { neuritis }\end{array}$ & $\begin{array}{c}\text { Whether on } \\
\text { treatment }\end{array}$ \\
\hline LL & $60 / \mathrm{M}$ & Relapsed 5 yr ago & $1+$ & + & - & + \\
\hline $\mathrm{LL}$ & $35 / \mathrm{M}$ & Relapsed 2 yr ago & $1+$ & + & - & + \\
\hline$\overline{\mathrm{LL}}$ & $33 / \mathrm{M}$ & $2 \mathrm{yr}$ & $3+$ & + & + & + \\
\hline LL & $45 / \mathrm{M}$ & $6 \mathrm{yr}$ & $4+$ & - & - & + \\
\hline LL & $45 / \mathrm{M}$ & $10 \mathrm{yr}$ & $2+$ & - & - & + \\
\hline LL & $45 / \mathrm{M}$ & $11 \mathrm{yr}$ & $3+$ & + & - & + \\
\hline BT & $35 / \mathrm{M}$ & $13 \mathrm{yr}$ & $-\mathrm{ve}$ & + & - & - \\
\hline BT & $45 / \mathrm{M}$ & 4 month & $-\mathrm{ve}$ & + & - & + \\
\hline BT & $30 / \mathrm{M}$ & $6 \mathrm{yr}$ & - ve & + & - & + \\
\hline BT & $40 / \mathrm{M}$ & $2 \mathrm{yr}$ & $-\mathrm{ve}$ & - & - & - \\
\hline BT & $50 / \mathrm{M}$ & 4 month & $-\mathrm{ve}$ & - & - & - \\
\hline
\end{tabular}




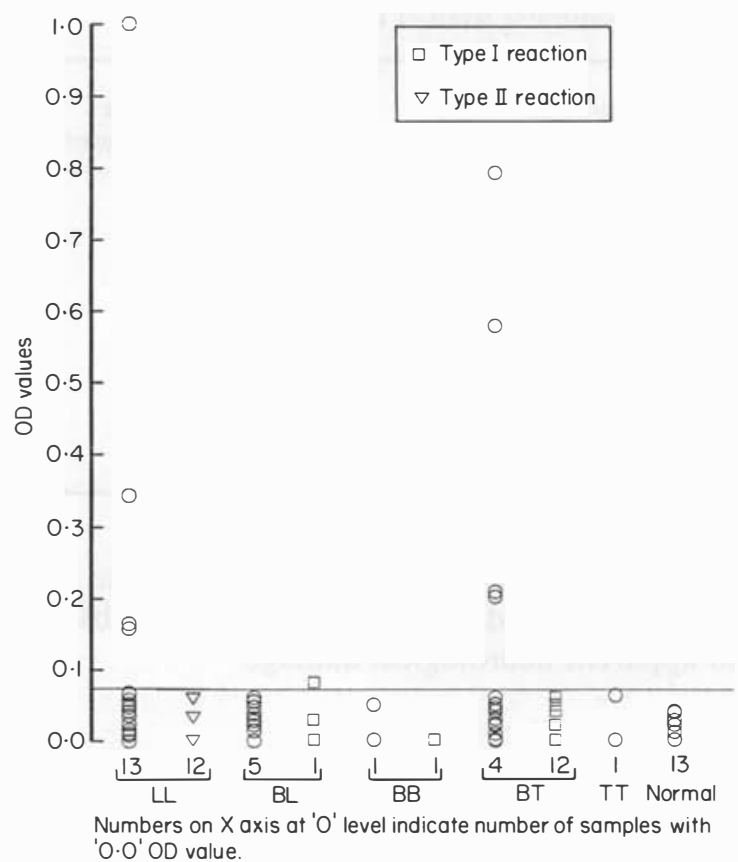

Figure 1. Optical density values with antigen derived from normal nerve using antilgG.

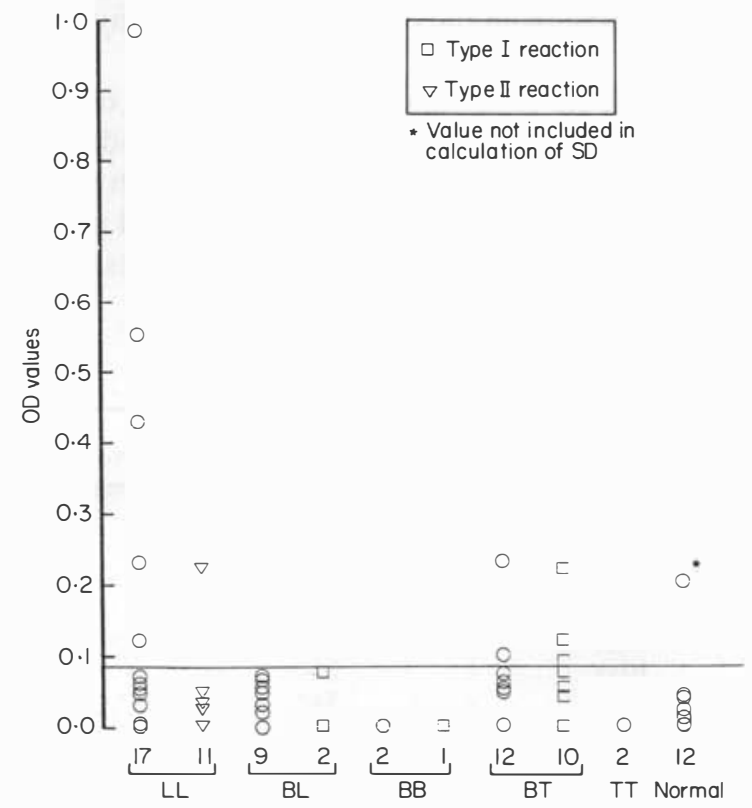

Numbers on $X$ axis at ' $O$ ' level indicate number of samples with 'O.O' OD value.

Figure 2. Optical density values with antigen derived from normal nerve using antiIgM. 
Table 6. Comparison of the various clinical and laboratory attributes of leprosy with the prevalence of significant levels of antineural antibodies of the IgG type

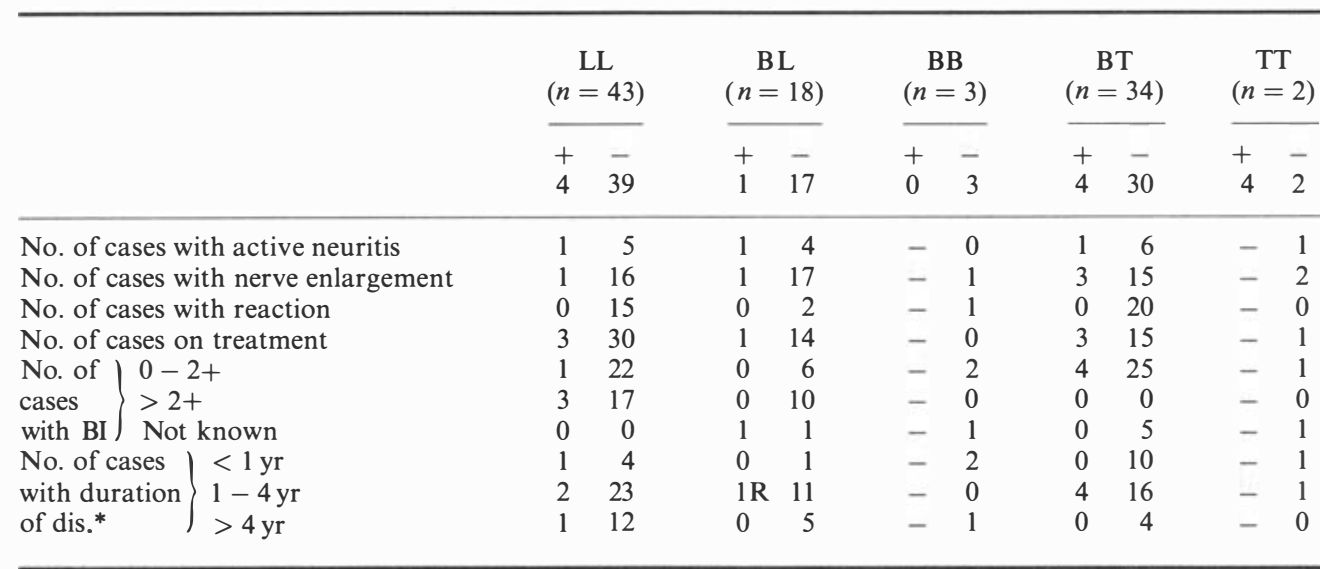

+ , No. of cases with significant levels of antineural antibodies; - , No. of cases without any significant levels of antineural antibodies; dis.*, disease; $\mathrm{R}$, relapsed case.

shown in Figures 1 and 2. A comparison of the clinical and laboratory attributes of leprosy with the prevalence of significant levels of antineural antibodies of $\operatorname{IgG}$ and IgM was done. The details are given in Tables 6 and 7 .

Using the $\chi^{2}$-test, there was no significant association $(P>0.05)$ between the type of leprosy, the BI and the presence of significant levels of antineural antibodies of the IgG or IgM type; nor was there any significant association $(P>0.05)$ between the treatment taken and the presence of detectable levels of antineural antibodies. Using Fisher's exact test, there was no significant association between the presence of detectable levels of antineural antibodies and nerve enlargement, active neuritis and duration of the disease.

Table 7. Comparison of the various clinical and laboratory attributes of leprosy with the prevalence of significant levels of antineural antibodies of the IgM type

\begin{tabular}{|c|c|c|c|c|c|c|c|c|c|}
\hline & $\begin{array}{c}\mathrm{LL} \\
(n=43)\end{array}$ & \multicolumn{2}{|c|}{$\begin{array}{c}\mathrm{BL} \\
(n=18)\end{array}$} & \multicolumn{2}{|c|}{$\begin{array}{c}\text { B B } \\
(n=3)\end{array}$} & \multicolumn{2}{|c|}{$\begin{array}{c}\text { BT } \\
(n=34)\end{array}$} & \multicolumn{2}{|c|}{$\begin{array}{c}\mathrm{TT} \\
(n=2)\end{array}$} \\
\hline & $\begin{array}{ll}+ & - \\
6 & 37\end{array}$ & $\begin{array}{l}+ \\
0\end{array}$ & $\frac{-}{18}$ & $\begin{array}{l}+ \\
0\end{array}$ & $\overline{3}$ & $\begin{array}{c}+ \\
5\end{array}$ & $\overline{29}$ & $\begin{array}{r}+ \\
0\end{array}$ & $\frac{-}{2}$ \\
\hline No. of cases with active neuritis & 1 & - & 5 & - & 0 & 0 & 7 & - & 1 \\
\hline No. of cases with nerve enlargement & 13 & - & 14 & - & 1 & 3 & 15 & - & 2 \\
\hline No. of cases with reaction & 14 & - & 0 & - & 0 & 3 & 2 & - & 0 \\
\hline No. of cases on treatment & 27 & - & 15 & - & 0 & 2 & 16 & - & 1 \\
\hline No. of $0-2+$ & 20 & - & 6 & - & 2 & 4 & 25 & - & 1 \\
\hline cases $>2+$ & 17 & - & 10 & - & 0 & 0 & 0 & - & 0 \\
\hline with BI Not known & 0 & - & 2 & - & 1 & 0 & 5 & - & 1 \\
\hline No. of cases $\mid<1 \mathrm{yr}$ & $0 \quad 5$ & - & 1 & - & 2 & 2 & 8 & - & 1 \\
\hline with duration $1-4 \mathrm{yr}$ & $2(1+R) 23$ & - & 12 & - & 0 & 1 & 19 & - & 1 \\
\hline of dis.* ${ }^{*}>4 \mathrm{yr}$ & $4(3+R) 9$ & - & 15 & - & 1 & 2 & 2 & - & 0 \\
\hline
\end{tabular}

+ , No. of cases with significant levels of antineural antibodies; -, No. of cases without any significant levels of antineural antibodies; dis.*, disease; R, relapsed case. 


\section{Discussion}

The results obtained after ELISA showed that $9 \%$ had significant levels of IgG antineural antibody and $11 \%$ had significant levels of IgM antibody. None of the normal controls had detectable levels of the IgG type of antineural antibodies, but 1 control $(5 \cdot 6 \%)$ had significant levels of IgM type of antineural antibody. There was no significant association with the type of leprosy, BI, treatment received, presence of nerve enlargement or active neuritis and the duration of disease.

Most of the patients with significant levels of antineural antibodies belonged to either the LL or BT group, but considering the fact that a large number of patients who were included in the study belonged to these 2 groups, in comparison with the other groups this was quite predictable.

Of the other neurological diseases tested for antineural antibodies, the sera from the 2 Gullian-Barré syndrome sufferers had significant levels of antineural antibodies of the IgG type and none of the others had significant levels. This was expected because the Gullian-Barré syndrome has a documented autoimmune pathogenesis. Thus these 2 sera have acted as positive controls for the ELISA test.

Similar to the results obtained in our study, Chujor et al. ${ }^{3}$ have reported $4 \cdot 1 \%$ of the leprosy patients and $5.6 \%$ of the normal sera positive for antineural IgG antibodies. Ghaswala et al. ${ }^{6}$ were not able to demonstrate any antibodies in their series as the optical density values of patients' sera were within those of normal controls. Thomas \& Mukherjee, ${ }^{16}$ on the other hand, have shown $100 \%$ positivity in all of their 258 sera tested. None of their normal controls were positive. Such variation in results are difficult to explain. The $100 \%$ positivity shown by this group ${ }^{16,11,12}$ has not been substantiated by any of the studies carried out so far. ${ }^{3,5,6,10,13,18}$

Benjamin et al., ${ }^{1}$ using immunoblot and antigen prepared from intermediate filament derived from human spinal cord, showed a high positivity of antineural antibodies $(47 \%)$ in leprosy patients, but the positivity in normal controls was also high, ranging from $20 \%$ in American subjects to $41.6 \%$ in Ethiopians. Eustis Turf et al. ${ }^{5}$ used indirect immunofluorescence and found $40 \%$ positivity in leprosy patients. Our study gave a $9 \%$ level of significant IgG antibodies in leprosy patients.

This variation in results is probably due to different kinds of antigens used. In the studies where human peripheral nerve antigen has been used, ${ }^{3,11,12,16}$ the type of proteins predominating in the preparation were probably different. The major protein in experiments by Chujor et al. ${ }^{3}$ was PNS myelin protein Po with $28 \mathrm{kDa}$ mol.wt, whereas, in the antigen prepared by Thomas \& Mukherjee ${ }^{16}$ there was a major band in the $40-70 \mathrm{kDa}$ mol.wt. The SDS-PAGE protein analysis of the antigen used in this study showed bands migrating at about $15-22 \mathrm{kDa}$ and $25-$ $27 \mathrm{kDa}$.

Other studies using animal nerve as antigen have found varying percentages of positivity. Wright \& Hirst, ${ }^{18}$ using rat sciatic nerve, found $25 \%$ positivity, but $22 \cdot 2 \%$ of normal controls were also positive. Mshana et al. ${ }^{10}$ used bovine sciatic nerve myelin basic protein and found $13 \%$ positive and Om Parkash et al. ${ }^{13}$ used rabbit nerve and found $22 \%$ positive. However, we have used human peripheral nerve as the source of antigen. This might explain the differences in these results and the results obtained by us.

In our study the number of leprosy patients with significant levels of IgM antineural antibodies (11\%) were more than those with detectable levels of IgG antibodies $(9 \%)$. 
Patients with significant levels of IgM antibodies belonged only to the LL and BT group. However, again considering the fact that a large number of patients who were included in the study belonged to these 2 groups in comparison with the other groups, this was quite predictable. Thomas \& Mukherjee ${ }^{16}$ tested only 35 patients with antihuman IgM conjugates. They obtained IgM antibody titres in the range of $0 \cdot 14$ to $0 \cdot 67 \mathrm{OD}$. We have also obtained values in a similar range, with only 1 lepromatous leprosy patient having a high value of $0.984 \mathrm{OD}$. Chujor et al. $^{3}$ also characterized antineural antibodies with respect to immunoglobulin classes and found that the antibodies they detected belonged mainly to the $\operatorname{IgG}$ and $\operatorname{IgM}$ class. However, Benjamins et al., ${ }^{1}$ using intermediate filament fraction of the human spinal cord as an antigen, were not able to detect any IgM antibodies using the immunoblot technique. Others $5,13,18$ did not study the sera for antineural antibodies of the IgM type. IgM antibodies are the earliest antibodies to appear. However, in our study, there was no significant association between the presence of $\operatorname{IgM}$ antibodies and a recent onset of the disease. We looked for such an association because IgM antibodies are usually associated with the early stages of any infection.

\section{Conclusions}

This study is not able to demonstrate any statistically significant levels of antineural antibodies associated with any type of leprosy, or any specific feature of the disease $(P>0.05)$. It cannot be said with any certainty that an autoimmune pathogenesis exists for neuropathy in leprosy. However, further studies will be required to confirm this assumption.

\section{Acknowledgments}

We are grateful to Dr U. Sengupta, Department of Immunology, the Central JALMA Institute for Leprosy, Agra for permission to use the facilities in his laboratory, to $\mathrm{Dr}$ S. K. Trivedi for providing the nerves for the antigen preparation and also to $\mathrm{Mr}$ V. Kamalanthan and Miss D. Kalaiselvi for typing the manuscript.

\section{References}

${ }^{1}$ Benjamins JA, Callahan RE, Runft D, Gerras G, Lefford MJ. Antineural antibodies in leprosy sera: further characterisation of antigens. J Neuroimmunol, 1989; 21: 125-35.

2 Boddingius J. Mechanisms of nerve damage in leprosy. In David Humber (Ed). Immunological aspects of Leprosy, Tuberculosis and Leishmaniasis, Excerpta Medica, Oxford. 1981, pp. 64-73.

3 Chujor SNC, Regele H, Bernheimer H, Levis W, Schwerer B. Serum antibodies against peripheral nervous system antigens in leprosy. Int J Lepr 1991; 59: 590-6.

4 Dastur DK, Mohan JR, Shah JS. Ultrastructure of nerves in tuberculoid leprosy. Neurol (India), 1972; 20: 89-99.

5 Eustis Turf EP, Benjamins JA, Lefford MJ. Characterisation of the antineural antibodies in the sera of leprosy patients. J Neuroimmunol, 1986; 10: 313-30.

${ }^{6}$ Ghaswala PS, Mistry NF, Antia NH. Serum antibodies of normals and leprosy patients show equal binding to peripheral nerve. (Letter to the Editor). Int J Lepr, 1989; 57, 3: 690-2.

7 Job CK. Pathology of peripheral nerve lesions in lepromatous leprosy. A light and electron microscopic study. J Neurol Sci, 1971; 29: 423-41. 
8 Job CK, Desikan KV. Pathologic changes and their distribution in lepromatous leprosy. Int J Lepr, 1968; 36: $257-70$.

9 Lowry OH, Rosebrough NJ, Farr AL, Randall RJ. Protein measurement with Folin phenol reagent. J Biol Chem, 1952; 193: 265-75.

${ }^{10}$ Mshana RN, Harboe M, Stones GL, Hughes RAC, Kadlubowski M, Belehu A. Immune response to bovine neural antigens in leprosy patients. 1. Absence of antibodies to an isolated myelin protein. Int J Le pr, 1983; 51, 1: 33-40.

11 Mukherjee R, Itty BM, Yadava A, Kharat I, Talwar GP. Characteristics of Antineural antibodies in leprosy patients. Po 317-Abstracts of Congress papers. Int J Lepr, 1989; 57, 1: 359.

12 Mukherjee R, Thomas BM, Vemuri N, Talwar GP. Nerve antigen based serological tests for the diagnosis and prognosis of leprosy. Trop Med Parasitol, 1990; 41: 357-8.

13 Parkash O, Srrevasta, Sengupta U. An attempt to demonstrate antinerve antibodies in leprosy sera using rabbit nerve as an antigen. Letter to Editor. Int $J$ Le pr, 1990; 58, 1: 129-30.

14 Ridley DS, Job CK. The pathology of leprosy. In Leprosy. Hastings (Ed). Churchill Livingstone, New York. 1985, pp. 100.

15 Ridley DS, Jopling WH. Classification of leprosy according to immunity-a five group system. Int J Lepr, 1966; 34: 255-73.

16 Thomas BM, Mukherjee R. Antineural antibodies in sera of leprosy patients. Clin Immunol Immunopathol, 1990; 57: 420-9.

17 Wright DJM. Auto antibodies in leprosy. Letter to Editor, Lancet, 1973; ii: 40.

18 Wright DJM, Hirst RA. Neural auto antibodies in leprosy. Lepr Rev, 1975; 46: 157-67. 